\title{
Więź małżeńska jako doświadczanie miłości w ujęciu chrześcijańskim
}

\section{Marital Bonds as an Experience of Love in the} Christian Perspective

\begin{abstract}
ABSTRAKT
Przeżywanie miłości jest najbardziej ludzkim i powszechnym doświadczeniem. Miłość jest rzeczywistościq złożonq, wieloaspektowq psychicznq i duchowq. To wartość uniwersalna i ponadczasowa. Zwiqzana jest z największa potrzebq ludzkq bycia kochanym i pragnieniem miłowania. Dlatego też w integralnym rozwoju osoby jest ona najważniejszym czynnikiem, który kształtuje i scala jej osobowość. Istota miłości jest niezmienna, natomiast sposoby jej przeżywania i wyrażania sq bardzo różne. Rozwój miłości małżeńskiej wymaga rozwoju więzi małżeńskiej. To dzięki niej możliwe jest integralne połączenie się dwóch osób w miłości. Więź małżeńska jest podsławowym elementem, który scala i wyraża wielopłaszczyznowy obszar małżeńskich relacji, interakcji i komunikacji.

Obecnie, w dobie konsumpcjonizmu oraz rozpowszechniania się stylu życia w zwiq̨zkach partnerskich, można zauważyć, że miłość i więź małżeńska nie sq wartościami, często wręcz mówi się o nich wstydliwie. W zwiqzku z tym, celem artykułu jest przedstawienie w ujęciu chrześcijańskim teoretycznych zagadnień odnoszących się do doświadczania miłości szczególnie w perspektywie więzi małżeńskiej. Uwzględniając złożoność tej problematyki, zostanq ukazane tylko
\end{abstract}

StOWA KLUCZOWE miłość, miłość małżeńska, matżeństwo, relacje międzyludzkie, więź matżeńska

\section{KEYWORDS}

love, marital love, marriage, interpersonal relationships, marital bond

SPI Vol. 23, 2020/1

ISSN 2450-5358

e-ISSN 2450-5366 DOI: 10.12775/SPI.2020.1.003

Nadesłano: 26.03.2020 Zaakceptowano: 7.05.2020

Artykuły i rozprawy 
wybrane jej aspekty. Omówione zostanq różnorodne konteksty miłości oraz doświadczanie i przeżywanie miłości małżeńskiej. Ukazana będzie istota i wartość więzi małżeńskiej, a także kwestia rozwijania zdolności do miłości w procesie wychowania człowieka.

\section{ABSTRACT}

Living love is the most human and universal experience. Love is a complex, multifaceted, psychological and spiritual reality. It is a universal and timeless value. It is associated with the greatest human need to be loved and the desire to love. Therefore, in the integral development of a person, love is the most important factor that shapes and integrates his/her personality. The essence of love is unchangeable, but the ways of experiencing and expressing it are very different. The development of conjugal love requires the growth of a marital bond. It is thanks to it that it is possible for two people to be united in love. A marital bond constitutes an essential element which integrates and shapes the multifaceted area of marital relationship, interaction and communication.

Nowadays, in an era of consumerism and a lifestyle based more on civil partnerships, it can be seen that love and marriage are not treated as the values, they are often even spoken of with shame. Therefore, the aim of the article is to present theoretical issues related to the experience of love in a Christian perspective, especially from the perspective of a marital bond. Taking into account the complexity of this issue, only selected aspects will be shown. The various contexts of love and the experience of marital love will be discussed. The essence and value of the marital bond will be shown, as well as the aspect of developing the ability to love in the process of human education.

\section{Wprowadzenie}

Współcześnie, w dobie informatyzacji, technicyzacji, konsumpcyjnego stylu życia oraz kryzysu wartości, jesteśmy świadkami chaosu aksjonormatywnego, w wyniku czego miłość jest utożsamiana z zakochaniem oraz z realizacją potrzeb psychoseksualnych. Miłość jest pojęciem bardzo często używanym, a nawet nadużywanym. Pojęciu temu różne osoby, a nawet całe środowiska nadają zupełnie odmienne znaczenia. Zdaniem Waldemara Furmanka obecnie rozwija się powszechny analfabetyzm miłości, gdyż przez błędne koncepcje został 
rozmyty i zredukowany jej sens antropologiczny, co oznacza, że miłość jest zagubioną wartością (por. Furmanek 2011: 251).

Miłość jest rzeczywistością złożoną, wieloaspektową, psychiczną i duchową. Zawsze jednak pozostaje związana $\mathrm{z}$ największą potrzebą ludzką bycia kochanym i pragnieniem miłowania. Dlatego też w integralnym rozwoju osoby jest ona najważniejszym czynnikiem, który kształtuje i scala jej osobowość. „W wymiarze osobowym prawdziwa miłość jest czynnikiem szczęściodajnym, stanowi częstokroć część życia, pozwala na przezwyciężenie poczucia osamotnienia, staje się siłą motoryczną wszelkich poczynań i jako taka jest niewątpliwie największą wartością. Kochać i być kochanym to czuć się potrzebnym, korzystać z większego poczucia bezpieczeństwa, być szczęśliwym” (Gajda 2004: 305).

Obecnie, w dobie rozpowszechniania się stylu życia w związkach partnerskich, można zauważyć, że miłość i więź małżeńska nie są wartościami, często wręcz mówi się o nich wstydliwie. „Młodzi ludzie nie zawsze właściwie przygotowani do przeżywania miłości, traktują ją jako przyjemność, nie potrafią rezygnować z własnego egoizmu, nie są w stanie robić coś bezinteresownie dla innych. Brak im cierpliwości, wspólnego działania na rzecz wzajemnego rozwoju" (Wolny 2008: 118). W związku z tym, celem artykułu jest przedstawienie w ujęciu chrześcijańskim teoretycznych zagadnień odnoszących się do doświadczania miłości szczególnie w perspektywie więzi małżeńskiej. Uwzględniając złożoność tej problematyki, zostaną ukazane tylko wybrane jej aspekty. Omówione zostaną różnorodne konteksty miłości oraz doświadczanie i przeżywanie miłości małżeńskiej. Ukazana będzie istota i wartość więzi małżeńskiej, a także kwestia rozwijania zdolności do miłości w procesie wychowania człowieka.

\section{Różnorodne konteksty miłości}

Miłość jest wpisana w ludzką naturę. Rodzi się, istnieje i rozwija się dzięki człowiekowi, ma różne oblicza i występuje pod różnymi postaciami, jako uczucie, postawa, wartość oraz cel, do którego pragnie się dążyć. Od strony afektywnej miłość to „głębokie uczucie do drugiej osoby, połączone zwykle $z$ silnym pragnieniem stałego obcowania z nią i chęcią obdarzenia jej szczęściem, któremu towarzyszy pociąg fizyczny do osoby będącej obiektem tego uczucia" 
(Stownik wspótczesnego języka polskiego 1996: 524). Opisywana jest jako silne i głębokie uczucie empatyczne, które sprawia, że człowiek zaczyna myśleć i czuć kategoriami osoby kochanej (por. Gajda 2004: 305). Należy również stwierdzić, że pojęcie miłości określa także różne jakościowo procesy uczuciowe. Można więc mówić zarówno o miłości erotycznej, która przyczynia się do zmiany w postrzeganiu świata, pozwalając na pełną wspólnotę z drugim człowiekiem, oraz o miłości zrodzonej z potrzeby wspólnoty, pozbawionej elementów seksualnych, a także o miłości rodzinnej i abstrakcyjnej (por. Imieliński 1980: 48). Miłość nie może się odnosić tylko do sfery uczuć i przeżyć człowieka. Jest wartością uniwersalną i ponadczasową. Bardzo istotna jest postawa miłości, która jest stałą dyspozycją, zakładająca poznanie, umiłowanie oraz działanie $\mathrm{w}$ kierunku przedmiotu miłości. Dlatego miłość w kontekście postawy zawiera trzy ważne elementy: intelektualny, emocjonalny oraz działaniowy. Komponent intelektualny odnosi się do wiedzy o kochanej osobie, emocjonalny dotyczy pozytywnych uczuć i pragnienia dobra dla tej osoby, a działaniowy wyraża się w podejmowaniu konkretnych działan dla jej dobra.

Miłość określana jest także jako silne przywiązanie do drugiego człowieka, stan gotowości do bezinteresownego oddania się, służenia komuś (por. Stownik wspótczesnego jezzyka polskiego 1996: 524) oraz nadrzędne nastawienie, kierujące wyborami człowieka, które dotyczą zarówno postępowania, jak i reagowania wobec tych, na których mu zależy (por. Gray 2010: 238). Łączy się z odpowiedzialnością za siebie i drugiego człowieka, bowiem „im więcej poczucia odpowiedzialności za osobę, tym więcej prawdziwej miłości” (Wojtyła 1986: 117). Miłość respektuje godność drugiej osoby, towarzyszą jej ethos i sumienie (por. Kowalczyk 2002: 106).

W kontekście relacji międzyludzkich miłość rozumiana jest jako proces, który rozgrywa się pomiędzy dwojgiem ludzi będących w związku (por. Wojciszke 2003: 8). Spełnia ona ważną rolę w zakresie doboru partnerów do małżeństwa oraz skłania małżonków do przyjęcia przeznaczenia, jakim jest małżeństwo, a także jest podstawą tworzenia hierarchii postaw, ról, celów czy też zadań wynikających z zawartego związku małżeńskiego (por. Rostowski 1987: 10-11).

Miłość jest wielką tajemnicą życia, która zawiera w sobie ryzyko, gdyż kierując ją ku drugiej osobie, czyni się to w nadziei, że zostanie ona przyjęta i odwzajemniona (por. Hill 1994: 247). Ponadto jest 
ona w dużym stopniu zagadką egzystencjalną, tajemnicą niedostatecznie wyjaśnioną, która wiąże się z uwolnieniem człowieka od poczucia osamotnienia oraz nadaniem jego życiu szczególnego sensu (por. Imieliński 1980: 271).

Niewątpliwie „miłość rozciąga się na wszystkie relacje człowieka: z samym sobą, z przyrodą, z innymi ludźmi, z Bogiem oraz przybiera bardzo różne formy" (Kuźma, Łuczyński 2004: 312). Jako szeroko rozumiane pojęcie, zjawisko czy też stan, charakteryzuje się również swoistym dynamizmem, a to z kolei warunkuje jej zmienność w czasie i nasileniu. Miłość jest najważniejszym wydarzeniem pomiędzy narodzinami a śmiercią każdego człowieka, które podlega ciągłym zmianom (por. Wojciszke 2003: 5).

W perspektywie wychowania chrześcijańskiego miłość jest fundamentalną zasadą moralności. Jan Paweł II charakteryzuje ją jako zasadę, ideę, której ludzie podporządkowują swoje postępowanie, co łączy się ze zdolnością do miłowania oznaczającą gotowość świadomego poszukiwania dobra z innymi lub dla innych. Obszarem czy też najważniejszym terenem realizacji miłości jest małżeństwo (Wojtyła 1986).

Pojęcie miłości ma różne znaczenia, dlatego też dla zarysowania jej roli, czy też znaczenia w funkcjonowaniu związku małżeńskiego, należy uwzględnić ową różnorodność, ponieważ dzięki temu istnieje większe prawdopodobieństwo uzyskania bardziej odpowiedniego obrazu samego małżeństwa, a na jego tle roli miłości (por. Rostowski 1987: 64-65).

Podsumowując, zakres pojęciowy pojęcia miłości jest szeroki, wieloznaczny oraz subiektywny. Miłość zawsze była, jest i zapewne będzie inspiracją dla wielu artystów, pisarzy, ludzi kultury, gdyż ze względu na swoje bogactwo znaczeń i odmian oczekuje wciąż nowych ujęć i sposobów prezentacji. Niemniej jednak jest trudna do zdefiniowania, bowiem dla każdego człowieka może oznaczać coś innego. Niewątpliwie „człowiek nie może żyć bez miłości” (Jan Paweł II 1979: 10), dlatego tak ważne jest jej doświadczanie w codzienności życia. Należy zauważyć, że istota miłości pozostaje niezmienna, natomiast sposoby jej przeżywania i wyrażania są bardzo różne, ponieważ uzależnione są od wielu czynników, miedzy innymi takich jak cechy osobowe człowieka, system wyznawanych wartości, kultura, miejsce oraz czas. 


\section{Doświadczanie i przeżywanie miłości małżeńskiej}

Przeżywanie miłości jest najbardziej ludzkim i powszechnym doświadczeniem. Jedną $\mathrm{z}$ podstawowych potrzeb, jaką przejawia człowiek, jest „potrzeba miłości, kochania i bycia kochanym, a zatem potrzeba budowania więzi z innymi ludźmi” (Imieliński 1980: 54). Potrzeba ta warunkuje rozwój osoby, a doświadczanie miłości jest konieczne, aby człowiek mógł osiągać osobową dojrzałość. „Człowiek, poddając się miłości, zbiera budujące doświadczenia. Uczy się dobroci, życzliwości, empatii, otwiera się na innych, stara się ich lepiej zrozumieć" (Gajda 2004: 305). Należy zauważyć, że potrzeba kontaktu emocjonalnego oraz życiowe postawy wobec innych ludzi powodują, iż człowiek odczuwa chęć stworzenia wspólnoty. Pragnienie poczucia odpowiedzialności za osobę, akceptacja, zrozumienie i tolerancja, a także chęć do zaspokajania jej różnorodnych potrzeb, sprowadzają się do celu, jakim jest nastawienie do utrzymania trwałego i dozgonnego związku, którego podstawą będzie miłość (por. Imieliński 1980: 54-55).

Podstawę małżeństwa tworzy miłość małżeńska, która ,jest jednym $\mathrm{z}$ najtrudniejszych, ale $\mathrm{w}$ swym trudzie jednym $\mathrm{z}$ najpiękniejszych rodzajów miłości, która może łączyć dwoje ludzi” (Kuźma, Łuczyński 2004: 315). Wyróżnia się trzy płaszczyzny tej miłości: zmysłową, uczuciową i duchową. Są one ze sobą zintegrowane i powiązane. Miłość zmysłowa (seks) dotyczy znaczenia biologiczno-zmysłowego, zaspokaja i rozładowuje napięcie seksualne oraz prowadzi do przeżywania przyjemności. $Z$ kolei miłość uczuciowa (eros) jest zmienna, przemijająca i nie zapewnia trwałości. Natomiast dojrzałą i głęboką miłością jest miłość przeżywana na poziomie duchowym, osobowym (caritas, agape), przejawiająca się między innymi $\mathrm{w}$ bezinteresownym i wzajemnym darze $\mathrm{z}$ siebie (por. Błasiak 2012: 15-16; Tchorzewski 2015: 32).

W perspektywie chrześcijańskiej miłość małżeńska między kobietą i mężczyzną ukazywana jest głównie jako wybór. Jest to akt decyzji, wyboru, uznania drugiej osoby za kogoś, kto „do mnie należy”. Jej ważnym elementem jest poczucie przynależności, o czym świadczy to, że na żonę albo na męża używa się określeń „moja”, „mój”, których sens jest bardzo głęboki. Nie opisują one wspólnych uczuć, 
ale przed wszystkim przynależność (por. Tischner, Zańko, Gowin 2000: 168-169).

Miłość małżeńska spełnia szczególną rolę, jest bowiem takim sposobem życia, który zmierza do tego, aby przechodzić przez nie we dwoje. Dla chrześcijan relacja ta jest sakramentem. Jednak nie posiada ona jednorodnego charakteru, ponieważ zmienia się i przekształca wielokrotnie w trakcie swego rozwoju oraz odróżnia się specyficznymi cechami od innych rodzajów miłości (por. Braun-Gałkowska 1987: 15).

Miłość małżeńska posiada zespół cech oraz komponentów, które zwracają uwagę na jej wartość, jak również charakteryzuje się specyficzną naturą. Ich występowanie, jak i stopień natężenia w związkach małżeńskich uzależnione są w dużej mierze od indywidualnego charakteru każdego z nich oraz od osobistych przekonań i osobowości partnerów.

Wśród cech miłości małżeńskiej wyróżnia się troskę, odpowiedzialność, szacunek, nastawienie ku przyszłości, pragnienie wspólnego działania, pobudzanie aktywności, płodność, potrzebę stwarzania i wspólnych dokonań, porzucanie egoizmu, współodpowiedzialność. Z kolei elementami miłości małżeńskiej są: współobecność, wyłączność, współodczuwanie i wzajemne obdarzanie się sobą. W obszarze tej tematyki bardzo istotna jest także wartość więzi małżeńskiej, elementów ją tworzących, jak i umacniających.

Miłość małżeńska przejawia się na wielu płaszczyznach życia małżeńskiego, rozwija się oraz stanowi podstawę związku małżeńskiego. Ma wpływ na jego jakość i trwałość, przejawia się w różnych działaniach współmałżonków, co znajduje odbicie w jej sakramentalnym charakterze. Warunki rozwoju miłości małżeńskiej wkraczające w zakres chrześcijańskiego rozumienia związku małżeńskiego zakładają także dążenie małżonków do świętości. Odbywa się to za pośrednictwem wszelkich działań podejmowanych przez partnerów, które pozwalają na wyrażanie, umacnianie i pogłębianie niemal wszystkich obszarów małżeńskiego życia, w których podstawę stanowi miłość (por. Nosowski 2004: 60). Miłość małżeńska jest wartością duchową i fizyczną. W wymiarze duchowym prowadzi do małżeństwa, natomiast w wymiarach duchowym i fizycznym - do rodzicielstwa. Miłość małżonków, która jest daleka od egoizmu, gromadzi w nich siły 
oraz wzmacnia ich ducha. Potrzebna jest tu wzajemna bliskość, aby małżonkowie odnaleźli w sobie sens istnienia (por. Heilly 1983: 67).

W związku małżeńskim miłość ma zatem fundamentalne znaczenie, a jej rozwój zależy w głównej mierze od powiązania jej z innymi wartościami (por. Ryś 1999: 64). Dlatego niezwykle ważne jest, aby małżonkowie podobnie ją rozumieli i dawali temu wyraz w swych poglądach, wyobrażeniach, oczekiwaniach i działaniach (por. Rostowski 1987: 46).

Ze względu na to, że małżeństwo funkcjonuje zawsze w konkretnej społeczności, należy zwrócić także uwagę, iż ta społeczność wywiera wpływ na każdy związek małżeński poprzez normy prawne i religijne oraz przez środowiskowe normy obyczajowe, jak i przez nacisk opinii publicznej, co ma znaczenie dla trwałości związku małżeńskiego (por. Adamski 1984: 27-28). Dlatego też istotny jest zarówno odpowiedni dobór partnerów oraz umiejętność wspólnego wypracowywania podzielanej przez nich koncepcji miłości (por. Adamski 1984: 30-31).

Należy zauważyć, że miłość małżeńska zakłada wspólne trwanie w szacunku i szczęściu, wychowanie dzieci (miłość rodzicielska), wspieranie się u schyłku życia poprzez troskę, która przejawia się w miłości opiekuńczej. Wiążą się z nią określone zadania prokreacyjne, opiekuńcze, wychowawcze, które realizują się na różnych etapach życia człowieka, małżeństwa i rodziny (por. Gos 2014: 45). Miłość przeżywana w małżeństwie posiada dla ludzi wierzących sakramentalny charakter, co ma ważne znaczenie dla wspólnoty małżeńskiej będącej szczególnym rodzajem więzi. Dlatego też w dalszej części zostanie ukazana istota i wartość tej więzi.

\section{Istota i wartość więzi małżeńskiej}

Rozwój miłości małżeńskiej zakłada z konieczności rozwój więzi małżeńskiej. Pojęcie więzi oznacza relację bliskości, zażyłości, a także związek, łączność, spójność (Stownik wspótczesnego języka polskiego 1996: 1228). Termin ten jest różnie wyjaśniany oraz bywa trudny do zdefiniowania. Ciekawe i inspirujące jest metaforyczne porównanie tej relacji do mostu. Więź jest „stałym środkiem urzeczywistniania współbycia między nieusuwalnie odrębnymi i zawsze już danymi jednostkami. Więź nie usuwa dystansu. Przekracza go, ale również 
go gwarantuje. Jest bowiem mostem, a most nie zbliża brzegów rzeki, zostawia każdy $\mathrm{z}$ nich na swoim miejscu, podobnie jak dzieląca przestrzeń" (Delsol 2011: 170). Człowiek sam sobie nie wystarcza, potrzebuje wychodzenia $\mathrm{z}$ siebie ku innym, nawiązywania i rozwijania relacji. Aby żyć w relacji, osoba musi jednak pozostać sobą jako odrębna jednostka.„I ten paradoks obecności i nieobecności decyduje o charakterze więzi między ludźmi, którzy idą ku sobie nawzajem, ale pozostają w sobie" (Delsol 2011: 170).

Wyróżnia się różne rodzaje więzi, między innymi: społeczną, rodziną, małżeńską. Więź społeczna to ogół relacji, stosunków i zależności międzyludzkich, które łączą człowieka $z$ innymi osobami, grupami i instytucjami społecznymi. Nie jest zjawiskiem, które można bezpośrednio zaobserwować, ale mimo tego można ją zbadać poprzez opis jej intensywności, trwałości i zanalizować jej rozwój w kontekście zmian (por. Izdebska 2015: 120). Natomiast więź rodzinna to „kompleks sił przyciągających jej członków nawzajem do siebie i wiążących ich ze sobą" (Dyczewski 2002: 11). Można ją określić „jako pewien zespół odniesień oraz relacji między członkami rodziny, których podstawą jest świadomość wspólnej genealogii i związków genetycznych, zespół wspólnie wyznawanych wartości, norm, celów działania, przeżyć o charakterze emocjonalnym, w jakich przebiega życie danej rodziny" (Pająk 2010: 14).

Z kolei więź małżeńska jest szczególną relacją międzyosobową, najsilniejszą, najbardziej intymną oraz niezwykłą, jaka zachodzi między małżonkami. Jest podstawowym elementem scalającym małżeństwo i obejmującym wielopłaszczyznowy obszar małżeńskiej interakcji, czyli zarówno więź psychiczną, jak i uczuciową (por. Ryś 1999: 58). To dzięki niej możliwe jest integralne połączenie się dwóch osób w miłości. Wynika ona ze wspólnego ogniska domowego, będącego źródłem wszelkich życiowych celów, oraz obejmuje sferę uczuć, która jest bazą związku małżeńskiego. Więź małżeńska rozumiana jest także jako proces wzajemnego obdarzania i obdarowywania się sobą małżonków w kontekście poznawczym, uczuciowym i działaniowym. Dla ludzi wierzacych jest dodatkowo sposobem budowania relacji z Chrystusem (por. McDowell 1992: 146). Rzeczywistością, w której osoby mogą realizować, tworzyć i umacniać więź małżeńską, jest przede wszystkim ich własne ognisko rodzinne, które zakładają i które chcą postrzegać jako miejsce przekazywania życia. 
Więź małżeńska również wyraża się w codzienności ich życia, oraz w tym wszystkim, co nadaje mu wartość i sens (por. Heilly 1983: 67).

Tworzenie więzi między małżonkami wymaga ustalenia, przyjęcia i przestrzegania zasad, do których należą: wzajemny szacunek, poczucie odpowiedzialności za podjęte zobowiązania, zasada spokoju, poczucie bezpieczeństwa, poszanowanie praw, poglądów, zainteresowań i pracy partnera, wzajemne zrozumienie, tolerancja, wzajemna empatia małżonków, opanowywanie negatywnych emocji, a także powstrzymywanie się od rozmów w stanie podenerwowania.

Proces tworzenia oraz wzmacniania więzi małżeńskiej jest nie tylko skomplikowany, trudny do opisania, ale wymaga również nieustannej pracy i wysiłku ze strony partnerów w całym okresie trwania małżeństwa (por. McDowell: 265; Błasiak 2012: 20). Warto zaznaczyć, że zdrowa więź małżeńska polega na wzajemnym dawaniu i braniu. Natomiast przez wzajemne obdarowywanie się małżonków i wspólne podporządkowanie się obojga miłości Boga, która jest zasadą i źródłem ich miłości, małżonkowie odnajdują rzeczywistą jedność. W tym kontekście istotne jest postrzeganie małżeństwa jako związku, w którym ma miejsce dawanie i przyjmowanie (por. McDowell 1992: 21).

Do czynników, które przyczyniają się do umacniania więzi małżeńskiej, należą: wzajemne okazywanie uczuć przez małżonków, udane kontakty seksualne, emocjonalna zależność współmałżonków, podobieństwo kulturowe, wspólne zainteresowania i cele, aktywne uczestnictwo w życiu domowym, wiara i nadzieja w trwałość związku małżeńskiego oraz wspólne podejmowanie decyzji i ustalanie zasad (por. Tyszka 1979: 151).

Aby miłość małżeńska rozwijała się i nie uległa wygaśnięciu, konieczna jest troska i dbanie o więź, co ma się wyrażać w świadomej, nieustannej aktywności małżonków. W tym kontekście szczególne znaczenie ma współodczuwanie, współrozumienie oraz współdziałanie małżonków (por. Ryś 1999: 60; Ostaszewski 2008: 145). Współodczuwanie oznacza więź emocjonalną, która oparta jest na kontakcie osobowym. Uwzględnia ono otwartość w wyrażaniu uczuć, empatię, działania małżonków zmierzające do zaspokajania potrzeb partnera (por. Ryś 1999: 61). Realizowane są przy tym takie potrzeby małżonków jak: miłości, bezpieczeństwa, szacunku, czułości, opiekuńczości, podziwu, więzi, bliskości, samorealizacji oraz potrzeby religijne 
(por. Zalewska 2002: 14-16). Z kolei współrozumienie określane jest przede wszystkim jako kontakt małżonków, który pozwala na wymianę spostrzeżeń, doświadczeń, refleksji oraz dostrzeganie i rozwiązywanie problemów. Jest ono wynikiem prawidłowej komunikacji pomiędzy małżonkami, zarówno w aspekcie werbalnym, jak również pozawerbalnym. Obejmuje także aktywne wzajemne słuchanie i akceptację odmienności współmałżonka, czyli tolerancję (por. Ryś 1999: 61; Ostaszewski 2008: 147; Błasiak 2012: 19).

Występowanie i rozwój współodczuwania oraz współrozumienia w związku małżeńskim stwarzają podstawę do współdziałania, co przejawia się głównie troską o istnienie i trwałość domu rodzinnego. Obejmuje to także podział ról, realizowanie wspólnych zainteresowań i wartości (por. Ryś 1999: 62). Współdziałanie to może się realizować w małżeństwie na trzy różne sposoby w zależności od rodzaju tworzonego związku (por. Godorowski 1987: 205). Pierwszy typ współdziałania opiera się na wspólnym podejmowaniu decyzji przez małżonków, wzajemnym zaufaniu, szacunku i tolerancji. Realizuje sie on w małżeństwach opartych na partnerstwie, których celem jest wspólne dobro stworzonej rodziny i poczucie odpowiedzialności za nią. Z kolei drugi typ aktywności odnosi się do małżeństw, w których zakres podejmowanych decyzji i działań spoczywa na jednym z małżonków. Dochodzi w nich do dominującej roli jednego z partnerów oraz uległości drugiego. Natomiast ostatni rodzaj współdziałania dotyczy małżeństw, w których ma miejsce walka o uzyskanie przez jednego z partnerów dominacji i przewagi nad drugim (por. Godorowski 1987: 205). To niestety może doprowadzić do dysharmonii pomiędzy małżonkami, dlatego ważne są wspólne wartości i cele, jakie sobie oni stawiają. Powoduje to pogłębienie bliskości między nimi, a także przyczynia się do wzrostu poziomu wzajemnego zadowolenia partnerów, co w konsekwencji umacnia małżeństwo (por. Ryś 1999: 62-63).

Dlatego też istotne jest ukazanie zestawienia pozytywnych i negatywnych postaw małżonków, które odczytywane są jako elementy intymnej, zdrowej i bogatej więzi osobowej w małżeństwie.

Do pozytywnych postaw małżonków zalicza się: cierpliwość, szukanie dobra drugich, dawanie, bezinteresowność, prawdomówność, pokorę, życzliwość, zaufanie, brak zazdrości, realistyczny sposób patrzenia na siebie, odpowiedzialność, opiekuńczość, przebaczenie, 
badanie siebie, zadowolenie, wdzięczność, samokontrolę i opanowanie, pilność, dotrzymywanie tajemnicy, łagodność, współczucie, wrażliwość, grzeczność, uprzejmość, wierność (por. McDowell 1992: 154-156). Natomiast wśród negatywnych postaw małżonków wylicza się: niecierpliwość, szukanie własnego dobra, nastawienie wyłącznie na branie, interesowność, kłamliwość, pychę, nieufność, zazdrość, zarozumiałość, próżność, nieodpowiedzialność, myślenie o własnej opinii, krytykanctwo, narzekanie, niewdzięczność, pobłażanie sobie, brak opanowania, samozadowolenie, plotkarstwo, szorstkość, nieuprzejmość, niewierność (por. McDowell 1992: 154-156).

Przedstawione powyżej przymioty zachowań małżonków różnią się od postaw i zachowań, które powinny wynikać z dojrzałej miłości. W arsenale cech dojrzałej miłości należy wymienić ponadto poczucie humoru, które może dać równowagę codziennemu życiu. Niezwykle ważne są też indywidualne przyjaźnie zawierane przez małżonków, o które należy dbać będąc w związku małżeńskim, zaangażowanie rozumiane jako nastawienie na wspólne cele związane ze sprawami znajdującymi się poza małżeństwem i domem, przeżycie seksualne jako wyraz dzielonej intymności i miłości. Oprócz tego istotne jest także dzielenie się myślami i informacjami, prawdomówność wyrażająca się $\mathrm{w}$ wiarygodności i niezawodności, rozmowa rozumiana jako otwarta i szczera komunikacja, miłość obejmującą wzajemne troszczenie się, intymność, zaufanie i oddanie się drugiej osobie, zdolność dostosowania się pojmowana jako afirmacja unikatowości drugiej osoby, a także tolerancja, czyli akceptacja drugiej osoby (por. McDowell 1992: 200-202).

Przymioty te można traktować jako składniki czy też cechy osobowości i charakteru małżonków, które odgrywają ważną rolę w codziennym rozwoju miłości małżeńskiej. W tym kontekście łatwo zauważyć, że więź miłości jest wieloaspektowa, obejmuje integralne osobowości obu kochających się osób, a mianowicie wymiary: cielesny, społeczny, intelektualny i duchowy. Należy również zaznaczyć, że w ludzkiej naturze istnieje potrzeba rozwoju we wszystkich tych dziedzinach, co jest ważne dla zdrowia i pełnego rozwoju jednostki (por. McDowell 1992: 200-202). Podstawą i jednym z głównych elementów dobrej więzi małżeńskiej jest takie rozumienie miłości, dzięki któremu dochodzi do głębokiego przekonania, że szczęście, bezpieczeństwo i rozwój drugiej osoby stają się tak ważne, jak moje 
własne, a cele i wartości stają się priorytetem dla obojga małżonków. Ponadto ważna jest gotowość do ofiarności oraz potrzeba porzucenia egoizmu i nadmiernej troski o własne pragnienia i dążenia (por. McDowell 1992: 210, 214). Proces rozwoju miłości małżeńskiej wymaga od małżonków postawy współpracy i ofiarności oraz świadomego zmierzania do jej ciągłego rozwoju. W tym kontekście ważna jest akceptacja współmałżonka, która staje się początkiem dojrzałej miłości (por. Ryś 1999: 69).

Dojrzała miłość małżeńska charakteryzuje się następującymi cechami: zaangażowaniem małżonków w tworzenie i umacnianie wspólnych planów skierowanych na przyszłość, pragnieniem potomstwa, umiejętnością tworzenia jedności na wyższych płaszczyznach oraz współodpowiedzialnością małżonków za życie rodzinne i małżeńskie. Cechuje się również życzliwością, wrażliwością na potrzeby partnera, akceptacją i zrozumieniem, wzajemną pomocą małżonków w realizacji celów i pragnień (por Ryś 1999: 69). Oznacza ona również spokój, wzajemne zaufanie, poczucie bezpieczeństwa oraz pracę nad jakością więzi osobowej i ofiarność rozumianą jako postawa altruistyczna nastawiona na wzajemne obdarowywanie się (por. Rostowski 1987: 33-41). Natomiast znakiem dojrzałej miłości jest oddanie się na stałe, bowiem w chrześcijańskim pojęciu miłości małżeńskiej tkwi przekonanie, że należy czekać na pojawienie się prawdziwej miłości przed podjęciem decyzji o małżeństwie. Wówczas jest ona fundamentem i główną przyczyną jego zawarcia. To właśnie oddanie się na stałe oraz gotowość do ofiary i pracy nad więzią osobową jest kluczem do długich, szczęśliwych małżeństw (por. McDowell 1992: 254-256). Jednocześnie bezwarunkowa miłość współmałżonka akceptująca drugą osobę taką, jaką ona jest - powoduje jego wzrost w miłości i staraniach o rozwój więzi z partnerem, a zaufanie prowadzące do intymnej, głębokiej komunikacji okazuje się znaczącym czynnikiem w tej dziedzinie (por. McDowell 1992: 260).

Omówione powyżej czynniki wpływające na tworzenie się, rozwijanie i umacnianie więzi małżeńskiej, a także związane $z$ tym cechy dojrzałej miłości małżeńskiej, wymagają nieustannej pracy i wysiłku ze strony partnerów w całym okresie trwania małżeństwa. Dlatego tak ważne i niezbędne jest, aby człowiek kształtował i rozwijał w sobie zdolność do miłości. 


\section{Rozwijanie zdolności do miłości}

Podstawą właściwego przygotowania się do małżeństwa jest wychowanie do miłości. Dlatego też powinno ono „zajmować znaczące miejsce w szeroko rozumianej edukacji emocjonalnej" (Kuźma, Łuczyński 2004: 317). Sfera emocjonalna spełnia ważną rolę z życiu człowieka, bowiem w dużej mierze to właśnie od emocjonalnej dojrzałości osoby zależy wypełnienie życiowego powołania. Uczuciowość rozwija się głównie w kontaktach międzyludzkich. Dlatego istotne jest, by wychowywać młodych ludzi, zwracając uwagę na ich postawy względem siebie i innych. Warto promować takie zachowania, jak uczynność, działanie na rzecz innych, empatię i wrażliwość na losy drugiego człowieka, odpowiedzialność. Należy się uczyć dostrzegania wartości w drugiej osobie, jej wewnętrznego i zewnętrznego piękna, które pociąga. Trzeba wreszcie ukazywać miłość i więź małżeńską jako ważne i znaczące wartości w życiu każdego człowieka. Istotnym bowiem elementem tworzącym sytuacje wychowawcze i mającym duże znaczenie są wartości, szczególnie te, które są świadomie wprowadzane $\mathrm{w}$ procesie wychowania.

Prawidłowa więź między małżonkami jest podstawowym elementem, który łączy małżeństwo. Szczególną i ważną rolę w budowaniu tej jedności odgrywa prawidłowa komunikacja, zdolność rozwiązywania konfliktów oraz gotowość do przebaczania. Dlatego istotne i konieczne jest uczenie się dobrej, szczerej i otwartej komunikacji w zakresie potrzeb, uczuć, doświadczeń, życiowych planów oraz tego wszystkiego, co odnosi się do relacji małżeńskich i rodzinnych. Tworzenie więzi uwarunkowane jest bliskością małżonków. W związku z tym należy się uczyć budowania bliskości emocjonalnej, intelektualnej i działaniowej. Istotą bliskości jest wiarygodność, ufność, otwartość, prawdziwość uczuć. Jest ona procesem i podlega dynamicznym zmianom, dlatego trzeba dbać o jej prawidłowy rozwój. Emocjonalną bliskość można kształtować poprzez empatię i autentyczność w kontaktach interpersonalnych. Natomiast bliskość intelektualną można rozwijać przez współrozumienie wynikające z prawidłowej komunikacji, umiejętności słuchania oraz akceptowania drugiej osoby. Z kolei bliskość działaniowa rozstrzyga o rodzaju i kierunku działań osób, buduje i wzmacnia więzi oraz pomaga w realizacji wspólnych celów (por. Ryś, Greszta, Grabarczyk 2019: 245-246). 
Należy stwierdzić, że miłość przeżywana w okresie dojrzewania ma już swego rodzaju „zadatki” miłości małżeńskiej, gdyż w każdej miłości może być zawarta perspektywa zarówno małżeństwa, jak i rodzicielstwa. Z kolei miłość małżeńska jest w pewnym sensie „dwuetapowa”: w okresie narzeczeństwa jest spoiwem przygotowującym do zawarcia małżeństwa, a w małżeństwie - gwarantem jego szczęśliwego trwania. Dlatego w aspekcie wychowawczym i pedagogicznym „na szczególną uwagę zasługuje miłość małżeńska i miłość rodzicielska. Pomiędzy tymi pojęciami istnieje wiele związków przyczynowo-skutkowych, albowiem udana miłość małżeńska w dużej mierze warunkuje miłość rodzicielską do dzieci i vice versa” (Kuźma, Łuczyński 2004: 315). Natomiast postrzeganie miłości i związku małżeńskiego jako ważnego elementu życia człowieka może się przyczyniać do tworzenia społeczeństwa, w którym celem i wartością jest sama osoba. Ponadto daje to możliwość zakładania pełnych i szczęśliwych rodzin, żyjących według ogólnie przyjętych zasad moralnych, etycznych, społecznych i religijnych. Dlatego też tak ważna jest miłość pomiędzy małżonkami, którą należy wspierać i umacniać w ciągu całego ich życia małżeńskiego.

W rozwijaniu zdolności do miłości bardzo ważne znaczenie mają takie elementy jak: proces wychowania, wartości, opinie i prezentowane poglądy czy też zasady. Podobne jest w przypadku wzajemnych relacji i stylów wychowania, od których również zależy, czy więzi się wzmacniają czy też osłabiają (por. Olczak 2010: 40-41).

Niewątpliwie „największą klęską ludzkości jest wszystko to, co wpływa osłabiająco na rozwój zdolności do miłości człowieka, co destruuje i zubaża jego wnętrze psychiczne, pozbawia go radości przeżywania miłości w jej różnych kontaktach społecznych, czyni go rozpaczliwie samotnym, czyni go wrogiem drugiego człowieka" (Kuźma, Łuczyński 2004: 318).

Podsumowując, należy stwierdzić, że zdolność kochania nie jest dana człowiekowi w "gotowej” formie. Dlatego powinien on ją rozwijać i kształtować, ponieważ miłość „nadaje barw ludzkiej egzystencji, determinuje los poszczególnych osób i łączy się ściśle z sensem życia" (Gajda 2004: 305). 


\section{Podsumowanie}

Z niepokojem można dziś zaobserwować, że współczesny człowiek bardzo często preferuje całkowity relatywizm i związany z nim nihilizm wartości oraz pustkę aksjologiczną, moralną, religijną, światopoglądową. Wybiera indywidualistyczną utopię szczęścia, która niestety oderwana jest od miłości, prawdy, odpowiedzialności oraz od więzi międzyludzkich. A przecież kochać można kogoś, kto jest blisko. Do pokochania potrzebne jest prawdziwe spotkanie. „Każde spotkanie z drugim człowiekiem zawiera zarówno szansę, jak i zagrożenie rozwoju: każde $\mathrm{z}$ nich czegoś nam udziela lub zabiera, otwiera nas lub zamyka, wzbogaca lub zuboża” (Sujak 1987: 159). Każde spotkanie z drugim człowiekiem daje możliwość doświadczania i rozwijania prawdziwej miłości. Dlatego warto podjąć naukową refleksję nad tym, czy i jak w świecie ciągłego i szybkiego postępu, rozwoju internetu, elektroniki, masowych mediów, telefonów komórkowych i wszelkiego rodzaju aplikacji oraz udogodnień można znaleźć jeszcze miejsce na miłość i dla miłości, dla przeżyć i doświadczania relacji międzyludzkich, dla rozwijania więzi?

Niewątpliwie „doświadczenie siebie i otaczającego świata oraz uczenie się siebie i otaczającego świata posiada zatem swój szczególny horyzont i kontekst - obecności drugiego człowieka" (Gara 2017: 28). Choć współczesny człowiek coraz bardziej angażuje się w aktywność zawodową, to jednak można zaobserwować, że jest on coraz bardziej samotny. Dlatego tak ważne jest podejmowanie głębszej refleksji nad problematyką szeroko rozumianej miłości. O zagadnieniu więzi małżeńskiej jako doświadczaniu miłości warto mówić, pisać, przypominać i ją promować zarówno w aspekcie teoretycznym, jak również empirycznym. Bo miłość nie skończy się nigdy, trzeba jej samemu codziennie się uczyć i trzeba również uczyć jej innych.

\section{Bibliografia}

Adamski F. (1984). Socjologia matżeństwa i rodziny, Warszawa: Państwowe Wydawnictwo Naukowe.

Błasiak A. (2012). Oddziatywania wychowawcze w rodzinie. Zagadnienie wybrane, Kraków: Akademia Ignatianum; Wydawnictwo WAM.

Braun-Gałkowska M. (1987). Psychologia domowa. Matżeństwo - dzieci - rodzina, Olsztyn: Warmińskie Wydawnictwo Diecezjalne. 
Delsol Ch. (2011). Czym jest cztowiek? Kurs antropologii dla niewtajemniczonych, przeł. M. Kowalska, Kraków: Znak.

Dyczewski L. (2002). Więź między pokoleniami w rodzinie, Lublin: Towarzystwo Naukowe KUL.

d'Heilly A. (1983). Mitość i sakrament, przeł. M. Borsuk-Majewska, Warszawa: Instytut Wydawniczy Pax.

Encyklopedia pedagogiczna XXI wieku, red. T. Pilch, t. 3, Warszawa: Wydawnictwo Akademickie „Żak”.

Furmanek W. (2011). Mitość - zagubiona wartośc wspótczesnej pedagogiki, Rzeszów: Wydawnictwo Oświatowe „Fosze”.

Gajda J. (2004). Mitość, [w]: Encyklopedia pedagogiczna XXI wieku, red. T. Pilch, t. 3, Warszawa: Wydawnictwo Akademickie „Żak”, s. 305-311.

Gara J. (2017). Egzystencjalna problematyzacja poszukiwania, poznawania i tworzenia samego siebie, „Przegląd Pedagogiczny”, nr 2, s. 9-33.

Godorowski K. (1987). Konflikty matżeńskie: źródta i przyczyny, możliwości zapobiegania i rozwiazywania, [w:] M. Kozakiewicz, Z. Lew-Starowicz (red.), Wychowanie. Przysposobienie do życia w rodzinie, Warszawa: Wydawnictwo PZWL.

Gos A. (2014). Znaczenie postaw wobec matżeństwa i rodziny w budowaniu relacji interpersonalnych, „Fides et Ratio. Kwartalnik Naukowy”, nr 1(17), s. $35-49$.

Gray J. (2010). Dlaczego Mars zderza się z Wenus, przeł. B. Jóźwiak, Poznań: Dom Wydawniczy Rebis.

Hill N. (1994). Plan pozytywnego dziatania, przeł. E. Czerwińska, Warszawa: Wydawnictwo Studio Emka.

Imieliński K. (1980). Rodzina i dom. Mitość i seks, Warszawa: Instytut Wydawniczy CRZZ.

Izdebska J. (2015). Dziecko, dzieciństwo, rodzina, wychowanie rodzinne. Kategorie pedagogiki rodziny w perspektywie pedagogiki personalistycznej, Białystok: Niepaństwowa Wyższa Szkoła Pedagogiczna.

Jan Paweł II. (1979). Encyklika Redemptor hominis, Poznań: Pallottinum.

Kowalczyk S. (2002). Zarys flozofii cztowieka, Sandomierz: Wydawnictwo Diecezjalne.

Kuźma J., Łuczyński A. (2004). Mitość a wychowanie, [w]: Encyklopedia pedagogiczna XXI wieku, red. T. Pilch, t. 3, Warszawa: Wydawnictwo Akademickie „Żak”, s. 312-318.

McDowell J. (1992). Tajemnica mitości, przeł. A. Gandecki, Kraków: Wydawnictwo Towarzystwo Krzewienia Etyki Chrześcijańskiej.

Nosowski Z. (2004). Parami do nieba. Matżeńska droga świętości, Kraków: Biblioteka „Więzi”.

Olczak A. (2010). Wychowanie demokratyczne podstawa badania więzi w rodzinie, [w]: E. Bartkowiak, A. Dobrychłop, P. Prüfer (red.), Więzi. Dylematy egzystencjalne, Zielona Góra: Oficyna Wydawnicza Uniwersytetu Zielonogórskiego, s. 33-45. 
Ostaszewski M. (2008). Więź matżeńska fundamentem rozwoju wspólnoty matżeńskiej i rodzinnej, „Studia Elbląskie”, nr 9, s. 141-151.

Pająk J. (2010). Tendencje w zakresie ewolucji czynników stymulujących więź rodzinna, [w:] I. Janicka (red.), Rodzice $i$ dzieci w różnych systemach rodzinnych, Kraków: Oficyna Wydawnicza „Impuls”, s. 13-19.

Rostowski J. (1987). Zarys psychologii matżenstwa. Psychologiczne uwarunkowania dobranego związu matżeńskiego, Warszawa: Państwowe Wydawnictwo Naukowe.

Ryś M. (1999). Psychologia matżeństwa w zarysie, Warszawa: Centrum Metodyczne Pomocy Psychologiczno-Pedagogicznej MEN.

Ryś M., Greszta E., Grabarczyk K. (2019). Intelektualna, emocjonalna i dziataniowa bliskośc matżonków a ich gotowośc do rozwiqzywania konfliktów oraz przebaczania, „Fides et Ratio. Kwartalnik Naukowy”, nr 2(38), s. 221-254.

Stownik wspótczesnego języka polskiego. (1996). red. B. Dunaj, Warszawa: Zespół Wydawnictwa Wilga.

Sujak E. (1987). Rozważania o ludzkim rozwoju, Kraków: Znak.

Tchorzewski A. de (2015). Mitość, nadzieja, odpowiedzialność - warunkiem więzi w rodzinie, [w:] J. Karbowniczek, A. Błasiak, E. Dybowska (red.), Dziecko, rodzina, wychowanie. Wybrane konteksty, Kraków: Akademia Ignatianum w Krakowie; Wydawnictwo WAM, s. 25-45.

Tischner J., Zańko D., Gowin J. (2000). Przekonać Pana Boga, Kraków: Znak.

Tyszka Z. (1979). Socjologia rodziny, Warszawa: Państwowe Wydawnictwo Naukowe.

Wojciszke B. (2003). Psychologia mitości. Namiętność, intymnośc, zaangażowanie, Gdańsk: Gdańskie Wydawnictwo Psychologiczne.

Wojtyła K. (1986). Mitość i odpowiedzialność, Lublin: Towarzystwo Naukowe KUL.

Wolny B. (2008). Mitość-zagubiona wartość edukacji szkolnej, [w:] K.K. Przybycień (red.), Mitość w życiu człowieka. Przyczynek do rozważań o budowanie „Cywilizacji mitości”, Stalowa Wola: Fundacja Campus, s. 101-122.

Zalewska S. (2002). Relacje pomiędzy matżonkami po odejściu dzieci z domu.

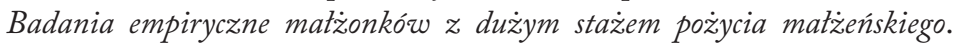
Warszawa: Wydawnictwo Sowa.

\section{ADRES DO KORESPONDENCJI}

\section{Dr Marzena Chrost}

Akademia Ignatianum w Krakowie

Wydział Pedagogiczny

Instytut Nauk o Wychowaniu

e-mail: marzena.chrost@ignatianum.edu.pl 